Отримано: 13 березня 2018 р.

Прорецензовано: 15 березня 2018 р.

Прийнято до друку: 19 березня 2018 р.

e-mail: yelena5678@ukr.net,

gontarvictoria@rambler.ru

DOI: $10.25264 / 2519-2558-2018-1(69) / 1-81-84$
Verovkina O., Hontar V. The comparative analysis of the stylistic functions of paradox in the works of E. Waugh and R. Dahl. Наукові записки Наиіонального університету "Острозька академія»: серія «Філологія». Острог : Вид-во НаУОА, 2018. Вип. 1(69), ч. 1, березень. С. 81-84.

\author{
Olena Verovkina, \\ Rivne State University of the Humanities \\ Viktoriia Hontar, \\ Rivne State College of Economy and Business
}

\title{
THE COMPARATIVE ANALYSIS OF THE STYLISTIC FUNCTIONS OF PARADOX IN THE WORKS OF E. WAUGH AND R. DAHL
}

The article is devoted to the comparative analysis of the stylistic functions of paradox in the novel of E.Waugh "Decline and Fall" and short stories by Roald Dahl.

There is some difficulty in studying paradox, which lies in the fact, that this phenomena has several meanings. Its explanation can be found in many dictionaries, encyclopaedias and references, as the term "paradox" is met in various spheres of human's thought, and used in Philosophy, Literature Study, Logics, Stylistics, Rhetoric. II is obvious, that each discipline uses the term of "paradox" to mark different things.

Due to the theoretical analysis of the scientific literature it was defined, that stylistic paradox is a grammatically correct utterance, a functional unit, which can take a form of a word up to the composite syntactic whole; it is characterized by logical and semantic contradictoriness of its components, expressed in its form and context; despite sound reasoning from acceptable premises, it leads to a conclusion that seems senseless, logically unacceptable, or self-contradictory but nonetheless it is true. Paradox can be characterized by the following features: alogism; simultaneous realization of contrast and alikeness relations; generalization; unexpectedness in interpretation of wellknown and common subject.

According to the syntactical organization of the contradiction in the works of fiction paradoxes are realized on the levels of: word combination, sentence, micro-context, and on the level of the literary work as a whole.

It was defined, that stylistic paradoxes of the novel "Decline and Fall" and short stories by Roald Dahl fulfil the following stylistic functions: demonstrative, persuasive, satirical and cognitive, among which the satirical function is presented by the greater number of the paradoxes, found in the works of both writers.

Key words: stylistic paradox, stylistic function, demonstrative, persuasive, satirical and cognitive functions.

Верьовкіна Олена Свгенівна,

Рівненський держсавний гуманітарний університет

Гонтар Вікторія Свгенівна,

Рівненський коледж економіки та бізнесу

\section{КОМПАРАТИВНИЙ АНАЛІЗ СТИЛІСТИЧНИХ ФУНКЦЙ ПАРАДОКСУ У ПРАЦЯХ І. ВО ТА Р. ДАЛЯ}

Статтю присвячено компаративному аналізу стилістичних функиій парадоксу у романі Івліна Во «Занепад $і$ руйначія» та оповіданнях Роальда Даля. 3'ясовано, шо стилістичний парадокс - ие функціональна одиниия, яка може набувати форми слова, словосполучення, а найчастіше складного синтаксичного иілого, характеризується протиріччям своӥх компонентів, алогізмом, узагальненням, але в-иілому є істиною. В прочесі аналізу творів визначені такі стилістичні функиї парадоксів: доказова, персуазивна, сатирична та когнітивна функції, при цуьому більиість парадоксів творів обох письменників вжито з метою створення сатиричного ефекту.

Ключові слова: стилістичний парадокс, стилістична функція, доказова, персуазивна, сатирична, когнітивна функиї.

Верёвкина Елена Евгеньевна,

Ровенский государственный гуманитарный университет

Гонтарь Виктория Евгеньевна,

Ровенский колледж экономики и бизнеса

\section{КОМПАРАТИВНЫЙ АНАЛИЗ СТИЛИСТИЧЕСКИХ ФУНКЦИЙ ПАРАДОКСОВ В РОМАНЕ И.ВО «УПАДОК И РАЗРУШЕНИЕ» И РАССКАЗАХ Р. ДАЛЯ}

Статья посвящена компаративному анализу стилистических функиий парадокса в романе Ивлина Во «Упадок и разрушение» и рассказах Роальда Даля. Выяснено, что стилистический парадокс - это функциональная единица, которая может существовать в форме слова, словосочетания, а чаше всего сложного синтаксического иелого, характеризуется противоречием своих элементов, алогизмом, обобщением, но в иелом истина. В процессе анализа произведений определень такие стилистические функиии парадоксов: доказательная, персуазивная, сатирическая и когнитивная функции, при этом больиинство парадоксов произведений обоих писателей употреблены с иелью создания сатирического эффекта.

Ключевые слова: стилистический парадокс, стилистическая функция, доказательная, персуазивная, сатирическая, когнитивная функции.

Paradox is a characteristic feature of many writers. However, although there have been conducted a lot of researches in the field of Literature Study, analyzing the creative works of O.Wilde, H.Chesterton and B.Show, studying, yet in Linguistics this problem is not completely investigated. 
There is also one more difficulty, which lies in the fact, that the phenomena of paradox has several meanings. Its explanation can be found in many dictionaries, encyclopaedias and references, as the term "paradox" is met in various spheres of human's thought, and used in Philosophy, Literature Study, Logics, Stylistics, Rhetoric. And it is obvious, that each discipline uses the term of "paradox" to mark different things.

It should be pointed out that general linguistic aspects of paradox were investigated in the works of V.A. Zviehintsev, N.D.Arutiunova, V.V. Odintsov, V.D.Dievkin, L.A. Nefiedova. From the position of Stylistics paradox was studied by H. Paliaro, H. Viliar, K.Komorovski, V.A. Uspenskyi, N.Y. Shpektorova, N.H.Yelina, H.A.Semen, V.V. Ovsiannikov, V.Z.Sannikov.

Some researches were devoted to defining the qualities of some paradoxical utterances. The pragmatics of such utterances was studied by B.T.Taneiv, lexico-semantic aspects were explained by V.I.Karasyk, E.B. Temiannikova, D.A. Kruze. The peculiarities of paradoxes, functioning in the communication acts were the subject of the research of P.Vatslavik, lingua-pragmatic aspects of this phenomenon were analyzed by Y.Y.Zhyhadlo.

Unlike metaphor, simile and antithesis, paradox is either not often mentioned in the list of stylistic devices or not completely described. Few articles on the topic can not fill in this gap.

Thus, the problem of paradox can not be solved without involving vast factual material, successive application of those methods, which can assist studying it from the point of Stylistics. Moreover, we consider, that the novel by Evelyn Waugh "Decline and Fall" and short stories of R. Dahl, which are good sources for the research on the stylistic function of paradox, still represent the subject of the scientific interest in terms of the topic under discussion.

Thus, the aim of our research is to make a comparative analysis of the stylistic functions of paradox in the novel of Evelyn Waugh "Decline and Fall" and short stories of Roald Dahl.

Linguists V.V. Odintsov and V.D.Dievkin interpret paradox as a deviation, which goes against the common language laws [2; 3]. Another group of scientists - O.K.Denisova, T.Y. Semen, N.Y. Shpektorova see paradox as a stylistic device and figure of speech $[1 ; 4 ; 9]$.

The definition of a paradox as a figure of speech is that it is a statement that contradicts itself. It also refers to a statement that starts with something that is true, but ends in something that is not acceptable [2].

A paradox is used to make the reader really consider the situation it presents. Often, this is a way to present an interesting concept or idea or to make a statement without stating an opinion outright.

However, the fundamental point in studying paradoxes is the understanding of paradox by E. Riesel, who considers it as a separate stylistic device[7].

It should be pointed out, that so far paradox has become one of the laws of literary creative work. O.M. Yashina suggests distinguishing several levels of paradox functioning in the literary text, namely: the level of a word combination, the level of a sentence, the level of micro-context, the level of context (or macro-context) [5].

We must admit, that in our opinion one should study the peculiarities of paradoxes functioning on the first three levels from the position of Stylistics, whereas the levels of context or macro-context demand the analysis of the whole literary work and would study the constructions, which can be referred to hermeneutic level.

Here we agree with the opinion of Belgian scientists, who consider what really matters in defining paradox is the presence of referential situation and the recipient's awareness of it. So, any pragmatic usage of the utterance immediately demands its pragmatic context.

For our study it is of major importance to emphasize on the various stylistic functions of paradox, which were defined by the Ukrainian researcher H.Y. Semen, who claims, that these functions are not always viewed as those for producing humorous or satirical effect. On the contrary, the device can be aimed at various stylistic tasks[9].

In particular, some functions of paradox are closely connected with each other. The function of demonstrability is closely connected with the function of persuasion. This function is executed by means of its brightness and attraction.

Moreover, paradox is used as a means to define contradictions of the reality. In this way it performs the function of delimitation between a humorous effect and the satirical one. Humor mostly emphasizes positive aspects, whereas satire is aimed at evil [3].

According to H.Y. Semen, paradox is also a means of consolidation of human cognitive activity [9].

All things considered, we will follow the above mentioned aspects as the leading principles for defining stylistic functions of paradoxes in the novel "Decline and Fall".

At the beginning of the book E. Waugh levels his guns at the English Universities.

"Have you at any time been locked up in hospital or home for mad people?

I was at Scone College, Oxford, for two years."

The protagonist of the novel is obliged to abandon the place in which he studies theology. Paul Pennyfeather, the serious student, returns at night to the university while a drunken brawl is in full progress in the quadrangle.

Pennyfeather is not a member either of a noble or wealthy family and that tiny detail is not to be forgiven at Scone College:

"But it is quite right. It isn't Rending. It's Penny Feather-someone of no importance".

At Llanabba School Pennyfeather becomes a teacher in spite of the fact that he has not completed his education. Dr. Fagan characterizes this fact as following:

"Now, I understand that you have had no experience? Of course, that in many ways an advantage."

The demonstrative idea of a fallen world is also portrayed in the novel through the institutions and some of the characters. Moreover, there are some other institutions that equally fail in the novel. One of them is the Church. When Dr. Fagan writes to Paul, he admits:

"...There is now a new type of vicar, called a "Modern Churchman", for whom religious belief is not a necessarily qualification."

One more paradox, which fulfils the demonstrative function in the novel is observed in the description of King's Thursday, a mansion of Margot, previously in a decayed state and now rebuilt as 'something clean and square' using ferro-concrete and aluminium, and eliminating "the human element from the consideration of form" 
It is Professor Silenus himself, the designer of the mansion, who says:

"Nothing I have ever done has caused me so much disgust. I hate every bit of it".

The second part of the book closes with Paul's arrest. And the author uses paradox to describe the event:

"Paul turned his brandy round in the glass... "To Lady Luck", he said. "She's been good to me!"

Which of you gentlemen is Paul Pennyfeather?...I'm Inspector Bruce of Scotland Yard. ... I am instructed to arrest you."

Thus, the demonstrative stylistic function of paradox is widely presented by the given examples.

The persuasive function of paradox is closely connected with its demonstrative one. At the very beginning of the novel the reader learns about the "reasons" of Bollinger club members to attack the rooms of unpopular students.

"There's Austin - he has a beautiful piano, I'm told. And Patridge will be another one. I think, he collects French paintings."

"Lord Rending can afford to hunt, but he collects teapots instead. And Sanders has won prizes for his poems, you know."

And afterwards, the later result is described, which also contain paradox, built on contrast.

"It was a lovely evening. They smashed Austen's piano, destroyed Patridge's French paintings, broke Sander's windows and Rending's teapots."

It should be pointed out, that satirical function of paradox is fulfilled by numerous paradoxes. When leaving Scone College, the porter tells Paul:

"I expect you'll be becoming a schoolmaster, sir. That's what most of the gentlemen does, sir, that gets sent down for indecent behaviour."

These two sentences sound paradoxical, as the schoolmaster is not supposed to behave outrageously.

"The Sports", one of the funniest chapters of the book, is a good example of paradox as well. Everything in the chapter is amusing but at the end of it amusement turns into delirium when the party is joined by Mrs. Margot Beste-Chetwynde and her "negro" lover. Nobody can understand "Chokie's" influence upon the lady: Even cool Prendergast dares to say:

"The mistake was giving them (meaning Chokie and black people in general) their freedom... They were far happier and better looked after before."

In the novel the reader notices oxymoron, which is also a paradox, used several times to mock at characters.

"We play in the village church. Do you play terribly well?"

When Paul is given a company of a large, frightening-looking mad man, appointed by the prison Governer to spend time as a therapy for him, he discovers, that the mad calls himself "a Chosen by God"; so, the reader feels disappointed. As it turns out, the mad man likes to read the Bible.

"Lady Dora's Secret", said God's chosen one, "Too soft for me. I prefer the Bible. There's a lot of killing in that. ... It's my purpose in life..."

As a matter of fact, the author uses paradox, built on the periphrasis "God's chosen one" to create a satirical effect. Later, we learn, that the mad man kills Prendergast by cutting off his head.

In the novel there are not so many paradoxes, fulfilling the cognitive function. This function can also be taken for an intellectual stylistic function of paradox, as it serves to intellectualize the novel and make the reader arrive to some conclusions about life. One of the few is the notice, written by Grimes to Dr.Fagan before Grime's faked death, which says:

"Those who live for worldly pleasure shall die of it."

This is the paradox, built on contrast and probably executing the aim to make the reader generalize some ideas of human's life.

As well as with E.Waugh, paradox is a favourite device of R.Dahl, though the writer uses it in somewhat different manner. It should be pointed out, that Roald Dahl's short stories always have an unexpected paradoxical ending and can be the subject of studying paradox on hermeneutic level. However, in this article we will analyze the stylistic functions of the device only on the level of a word, a word combination, a sentence and micro-context.

A lot of paradoxes can be found in the titles of Dahl's short stories. For instance, good examples can be found in the titles of "Parson's Pleasure", "Lamb to the Slaughter", Dip in the Pool", "The Way Up To Heaven", "Nunc Dimittis", where the paradox is used to create a satirical effect. Actually, it is this effect, which is presented by the largest percentage of all paradoxes, used by the author. In "Lamb to the Slaughter" a pregnant woman kills her husband with a lamb's leg for the reason he wanted to leave her. Then she puts the "evidence" in the oven and goes to the shop. On her coming back she calls the policemen and treats them with roasted meat, getting rid of the weapon of the murder. The policemen, looking for the weapon, are eating the lamb and discussing the case.

"Personally, I think it's right here on the premises."

"Probably right under our very noses. What you think, Jack?"

And in the other room, Mary Maloney began to giggle".

Moreover, in Christianity a lamb is a symbol of innocence and victim, so using such a title, the author hints on the woman, who killed her husband, yet is not suspected in the murder.

In the story "The Way Up to Heaven" the title can be interpreted in two ways. The woman, leaving her place for three weeks, understands, that her husband has got stuck in the elevator, but she does not take any measures to save him and commit a crime. So, the elevator becomes the way to heaven for her husband. On the other hand this situation can be a possibility for the woman to live a happy life without her husband.

The title of the story "Parson's Pleasure" also a paradox, because in the end of it the main character, who is disguised as a parson, does not get any benefit.

Another stylistic function, demonstrative one, is presented almost as frequently as the satirical one. In the short story "The Landlady" the mistress of the boarding house invites the customer sounding very politely.

"Please, come in"

The word please is marked by italics in the text, having an absolutely different meaning, because the woman has some interest in having customers just by killing them and making scarecrows of them.

Likewise, in the short story "Galopping Foxley" the paradox is an oxymoron, which is used to make Foxley's description brighter. 
"It was really an intolerable face, vulgarly, almost lasciviously handsome..."

And in "Parson's Pleasure" the paradox fulfils the same stylistic function on the level of a micro-context.

"He studied the Georgian house through his binoculars. It had a clean prosperous look, and the garden was well ordered. That was a pity."

The paradoxes with persuasive function are not so numerous in the short stories of R.Dahl. This is the example, taken from "Galloping Foxley"

"To burn Foxley's toast was a "beatable offence". So was forgetting to take the mud off Foxley's football boots. So was failing rolling up Foxley's brolly the wrong way round. So was banging the study room door when Foxley was working. So was filling Foxley's bath too hot for him...... So was leaving Foxley's study untidy at any time."

As for cognitive function in R.Dahl's short stories, it should be stressed out, that it is hardly observed.

The statistic indices of paradox functions in the works of E. Waugh and R.Dahl are given in the table.

Table 1

The distribution of paradoxes according to their stylistic functions

\begin{tabular}{|l|c|c|c|c|}
\hline \multirow{2}{*}{\multicolumn{1}{c|}{ Stylistic functions of paradoxes }} & \multicolumn{2}{c|}{ "Decline and Fall" by E.Waugh } & \multicolumn{2}{c|}{ Short stories of R.Dahl } \\
\cline { 2 - 5 } & in number & in \% & In number & in \% \\
\hline Demonstrative & 13 & $29 \%$ & 12 & $27 \%$ \\
\hline Persuasive & 7 & $16 \%$ & 3 & $7 \%$ \\
\hline Satirical & 21 & $48 \%$ & 28 & $64 \%$ \\
\hline Cognitive & 3 & $7 \%$ & 1 & $2 \%$ \\
\hline
\end{tabular}

So, having analyzed the equal number of paradoxes in the works by E.Waugh and R.Dahl we can conclude that in the works of both writers paradoxes mostly perform the satirical and demonstrative functions, though short stories contain more paradoxes used with the purpose to criticize and mock at the negative facts and phenomena, whereas in the novel demonstrative function is also of great importance.

Thus, the theoretical analysis of previous researches on paradox and the practical part of the article gives us an opportunity to admit that, stylistic paradox is a functional unit, which can take a form of a word up to the composite syntactic whole; it is the statement that, despite sound reasoning from acceptable premises, leads to a conclusion that seems senseless, logically unacceptable, or self-contradictory. However, this seemingly contradictory statement may nonetheless be true. In the novel of E. Waugh and short stories of R.Dahl paradox fulfills the following functions: demonstrative, persuasive, satirical and cognitive.

The further perspectives of the research lie in conducting further comparative analysis of paradoxes, used by other writers.

\section{Literature:}

1. Денисова О. К. К вопросу об использовании некоторых стилистических средств в пьесах Оскара Уайльда / О.К. Денисова // Вопросы лексикологии и стилистики романо-германских языков. Иркутск: Изд-во ИПИИЯ, 1972, вып. 1. - С. 73-85.

2. Девкин В. Д. Парадоксы в немецком языке / В.Д. Девкин // Иностранные языки в школе. 1988, № 2. - С. 15-21.

3. Одинцов В. В. Лингвистические парадоксы: кн. для учащихся ст. классов / В.В.Одинцов. - Изд-е 2-е. М.: Просвещение, 1982. $175 \mathrm{c}$.

4. Шпекторова Н. Ю. К вопросу о литературно-художественном парадоксе (на материале произведений О. Уайльда) / Н.Ю. Шпекторова // Вопросы лексикологии, лексикографии и стилистики романо-германских языков: сб. науч. трудов. Самарканд: Самарканд. гос. ун-т, 1975. С. 218-225.

5. Яшина Е.Н. Виды парадокса в художественном тексте / Е.Н. Яшина // Вестник Тамбовского университета. - 2007. - № 8. C. $280-288$.

6. Dahl R. You never know... / R. Dahl. - Moscow: "Tsitadel”, 2001. - 206p.

7. Riesel E. Abriss der Deutschen Stilistik / E. Riesel. - M.: Verlag fur fremdsprachige Literatur, 1954. - 402 S.

8. Waugh E. Decline and Fall / E. Waugh. - Oxford: Oxford University Press, 2001. - 120p.

9.Семен Г.Я. Лингвистическая природа и функционирование стилистического приема парадокса: на материале англ. Языка. - Режим доступа: http://www.dissercat.com/content/lingvisticheskaya-priroda-i-funktsionirovanie-stilisticheskogo-priema-paradoksa-namateriale 